\title{
Safe Transportation of Nuclear Fuel Assemblies by Means of Wheeled Robotic Platforms
}

- Alyokhina Svitlana, Dr. Sci. (Engin.), Senior Research Scientist

A. Pidhorny Institute of Mechanical Engineering Problems of the National Academy of Sciences of Ukraine, Kharkiv, Ukraine Kharkiv National University of Radio Electronics, Kharkiv, Ukraine ORCID: https://orcid.org/0000-0002-2967-0150

- Nevliudov Igor, Dr. Sci. (Engin.), Professor Kharkiv National University of Radio Electronics, Kharkiv, Ukraine ORCID: https://orcid.org/0000-0002-9837-2309

- Romashov Yurii, Dr. Sci. (Engin.), Docent Kharkiv National University of Radio Electronics, Kharkiv, Ukraine ORCID: https://orcid.org/0000-0001-8376-3510

Certain engineering problems concerning safety of the technological operations of the horizontal transportation of nuclear fuel within the enterprises' sites were considered. Taking into account current trends in the introduction of robotic systems to reduce the impact of hazardous nuclear materials on personnel, the issue of automated control of the movement of the wheeled robotic platform, which can be used for horizontal transportation of nuclear fuel was studied. The major attention was paid to minimizing the transportation loads on nuclear fuel by means of decreasing the accelerations under its horizontal movement on the robotic wheeled transportation platform, which is a separate issue of the comprehensive safety problem of nuclear materials management.

The research of horizontal movement safety of nuclear fuel by means of the robotic wheeled platforms was limited to defining transportation accelerations and was performed by computer simulations using mathematical models of dynamics and electro-mechanics. The mathematical model of the robotic transport wheeled platform loaded with nuclear fuel with the on-board accelerometer ensuring the required measurements necessary for an automated safe movement control system was built in the form of the Lagrange equations of the second kind and the electro-mechanics equations of the direct current electric motors. The issue of ensuring smooth running during the displacement of a wheeled platform loaded with nuclear fuel was investigated, since especially in this mode the maximum accelerations are observed, which can lead to nuclear fuel damage. Computer simulation was performed using free Scilab software with open program code. It was demonstrated that due to the proper choice of the time algorithm of the voltage of electric motors, it is possible to ensure a small acceleration during the displacement of a robotic wheeled transport platform loaded with nuclear fuel. The obtained result substantiated the possibility of safe horizontal transportation of nuclear fuel on robotic wheeled platforms within the territories of enterprises, which will significantly reduce the harmful impact of hazardous nuclear materials on industrial personnel.

Keywords: automation, nuclear fuel, handling, management, safety, wheeled transport platform, software control, smooth moving, mathematical model.

(c) Alyokhina S., Nevliudov I., Romashov Yu., 2021

\section{Introduction}

Transportation of nuclear fuel assemblies within enterprises' territories is the delicate technological operation due to necessity to fully exclude all possi- ble, even non-visible micro-damages which can lead to unpredictable events important for safety during nuclear fuel follows operation. It is obvious that possible transport damages of the nuclear fuel assemblies can be from loads due to not low enough transport accelerations. Therefore, there is the contradiction be- 
tween the wish to have faster transportation and possibility to damage nuclear fuel due to higher accelerations, which can occur if we will have to do it. One way to resolve this contradiction is in using the automated control of nuclear fuel transportation because it allows providing maximal permissible acceleration more smoothly compared to the manual control.

\section{Current State Overview the and Problem Formulation}

Almost of estimates of the nuclear fuel operability and safety are based on the assumption that all damages occurred before operation are negligible [1], [2]. At the same time, some damages are possible including due to transport operations and a lot of such damages of the nuclear fuel assemblies cannot be estimated due to limited opportunities of instrumental measuring, but these damages can having the significant influencing on the operational operability and safety due to opportunities of creating some unpredictable events which can be important for the nuclear safety. This research supplements the previous researches [1], [2] because of considering the problems about minimizing the possible transport loads on the nuclear fuel assemblies.

Necessity of increasing the industrial staff safety requires principally of implementing the different robotic systems for handling the radioactive dangerous materials, and due to this, it is one of modern trends in industry, especially in nuclear power [3]-[5]. The most up-to-date applications of the robotic systems for the nuclear power purposes are limited to important but auxiliary operations like inspecting the spent nuclear fuel [4] as well as aerial working [3], [4], [7] at the nuclear power plants including after the serious nuclear disasters like Chernobyl and Fukushima Daiichi [3] because it is possible to do it by using the well-known technologies including the remote control [8]. At the same time, direct handling the nuclear fuel assemblies requires a lot of especial characteristics of the robotic systems like the smooth motions, the minimal accelerations and the accuracies of positioning more precisely comparing with the general purposed robotics. All these are to minimize the damages in the nuclear fuel assemblies at their handling, so the purpose of this research is in developing the theoretical backgrounds of automated ensuring the smooth motions of wheeled robotic transport platforms required to minimize the transportation damages of the nuclear fuel assemblies. To accomplish this purpose the mathematical model of the dynamic for the electro-mechanic wheeled robotic transport platform with the board accelerometer and cargo of the nuclear fuel assemblies will be developed. Besides, using that proposed mathematical model, it will be executed the computer simulations of the nuclear fuel assemblies transportation process to show the possibilities of automated ensuring the smooth motions and instrumental recording the actual transport loadings.

\section{Mathematical model of horizontal transportation of the nuclear fuel assemblies on four-wheeled robotic platform}

The transportation loads on the nuclear fuel assemblies during the technological displacements are determined by their accelerations, so the mathematical model of the robotic transport platform should allow us defining these accelerations. The four-wheeled robotic transport platform for the nuclear fuel assemblies' horizontal displacements was considered (Figure 1) because it represents one of the most widely used designs [3]. Let us assume that the four-wheeled transport platform is driven by the electromechanical pair couples produced in the direct current electric motors separately for each of the wheels (Figure 1).

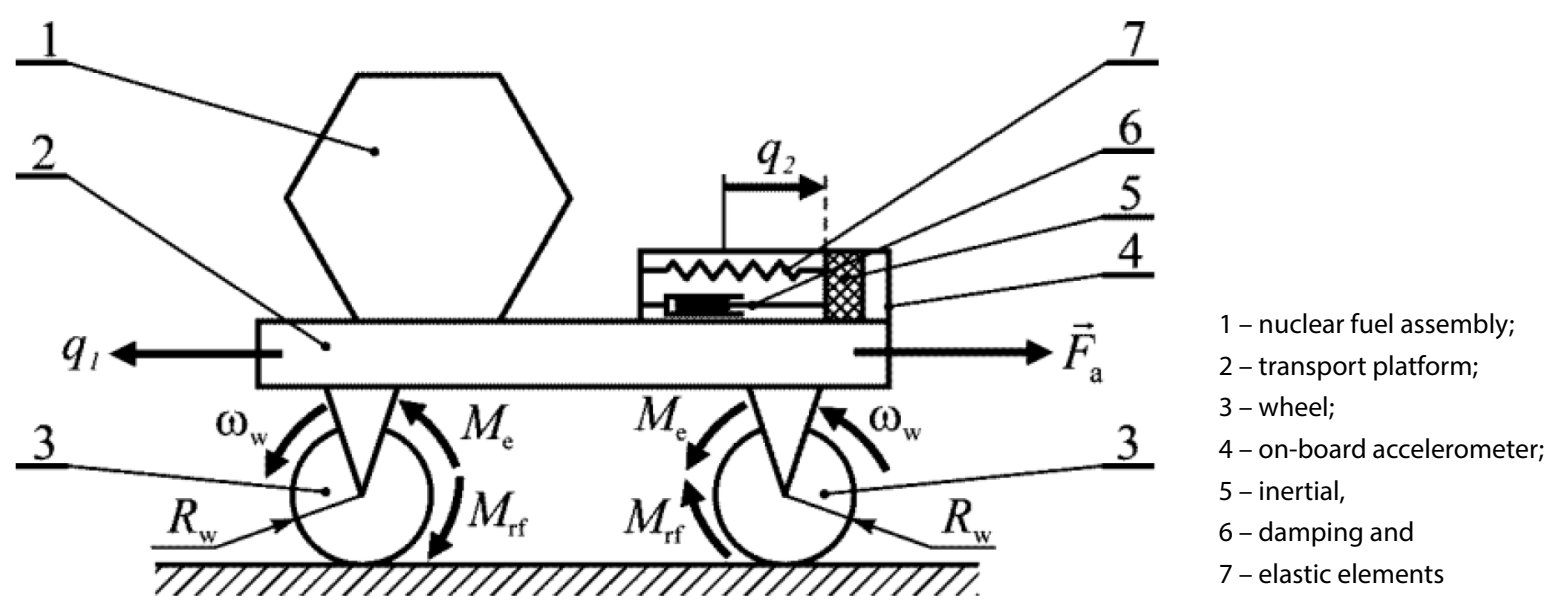

Figure 1 - Schematization the four-wheel transport platform with the nuclear fuel assembly cargo 
The impact of the moved wheeled platform on the installed board accelerometer will be considered to estimate the possibilities for accurate instrumental measurement and save data on the transport accelerations (Figure 1). Only the horizontal transport displacements of the nuclear fuel will be considered, so we will have the holonomic system with two freedom degrees representing the motion of the platform and the displacement of the inertial element of the accelerometer (Figure 1).

Using the well-known Lagrange equations of the second kind we will have the following differential equations of motion:

$$
\begin{gathered}
m \ddot{q}_{1}-m_{a} \ddot{q}_{2}=4 \frac{M_{\mathrm{e}}-M_{\mathrm{rf}} \operatorname{sign}\left(\dot{q}_{1}\right)}{R_{\mathrm{w}}}-b \dot{q}_{1}\left|\dot{q}_{1}\right| \\
-m_{a} \ddot{q}_{1}+m_{a} \ddot{q}_{2}=-c_{\mathrm{a}} q_{2}-\beta_{\mathrm{a}} \dot{q}_{2}
\end{gathered}
$$

where $q_{1}$ and $q_{2}$ are the generalized coordinates defining the horizontal motion of the wheeled platform and displacement of the inertial element of the accelerometer; $M_{e}$ is the electromechanical couple created by the drive electric motor; $M_{\mathrm{rf}}$ is the rolling friction couple; $R_{\mathrm{w}}$ is the radius of the wheels; $b$ is the coefficient defining the aerodynamic resistance force; $m_{a}$ is the mass of the inertial element, $\beta_{a}$ is the parameter of the damping element and $c_{a}$ is the stiffness of the elastic element of the accelerometer; $m$ is the equivalent mass of the wheeled platform taking into account all their kinetic energies.

In case of the wheels rolling without sliding, the equivalent mass of the robotic wheeled transport platform for the nuclear fuel assemblies' horizontal displacements is as follows:

$$
m=m_{\mathrm{NFA}}+m_{\mathrm{p}}+4\left(m_{\mathrm{w}}+m_{\mathrm{r}}+\frac{J_{\mathrm{w}}+J_{\mathrm{r}}}{R_{\mathrm{w}}^{2}}\right)+m_{\mathrm{a}}
$$

where $m_{\mathrm{NFA}}$ is the mass of the nuclear fuel assembly; $m_{\mathrm{p}}$ is the mass of the non- rotating components of the wheeled platform; $m_{w}$ and $m_{r}$ are the masses of the wheel and the electric motor's rotor; $J_{w}$ and $J_{r}$ are the moments of inertia of the wheel and the electric motor's rotor.

The triggering mode will be considered for the robotic wheeled transport platform transporting nuclear fuel assemblies because the maximum accelerations occur in this mode. The main difficulties in considering the triggering mode are due to the well-known properties of the rolling friction couple which for the case of equal platform's weight distribution between the wheels can be represented as follows:

$$
\begin{gathered}
\left|M_{\mathrm{rf}}\right| \leq M_{\mathrm{rf}}^{\max }, M_{\mathrm{rf}}^{\max }= \\
=f_{\mathrm{rf}}\left(m_{\mathrm{NFA}}+m_{\mathrm{p}}+4\left(m_{\mathrm{w}}+m_{\mathrm{r}}\right)+m_{\mathrm{a}}\right) g / 4
\end{gathered}
$$

where $M_{\mathrm{rf}}^{\max }$ is the maximal value of the rolling friction couple corresponding to the moving state; $f_{\text {rf }}$ is the rolling friction coefficient.

To consider the properties (4) of the rolling friction, it is necessary to represent the differential equation (1) as follows:

$$
m \ddot{q}_{1}-m_{a} \ddot{q}_{2}=\left(F\left(M_{\mathrm{e}}, q_{1}\right)+\left|F\left(M_{\mathrm{e}}, q_{1}\right)\right|\right) / 2,
$$

$$
\text { where } F\left(M_{\mathrm{e}}, q_{1}\right)=4 \frac{M_{\mathrm{e}}-M_{\mathrm{rf}}^{\max } \operatorname{sign}\left(\dot{q}_{1}\right)}{R_{\mathrm{w}}}-b \dot{q}_{1}\left|\dot{q}_{1}\right| \text {. }
$$

The differential equations (5), (2) have to be supplemented by the electro-mechanics equations defining the electro-mechanic couple of the direct current motor:

$$
\begin{gathered}
M_{\mathrm{e}}=B \cdot I(t), B=\sqrt{\frac{R\left(J_{\mathrm{w}}+J_{\mathrm{r}}\right)}{\tau_{M}}}, \\
L \frac{d l}{d t}+R \cdot I+\frac{B}{R_{\mathrm{w}}} \dot{q}_{1}=u(t),
\end{gathered}
$$

where $R, L$ and $\tau_{M}$ are the resistance, the inductance of the rotor's winding and the electromechanical constant of the direct current drive motor; $I$ is the electric current of the rotor winding and $u(t)$ is the supplied voltage of the direct current drive electric motor.

The ordinary differential equations defined by the relations (5), (2) and (6), (7) have to be considered with the initial conditions defining the state at the initial time $t$ moment, which is chosen as $t=0$. Taking into account the considered triggering mode, the initial conditions are as follows:

$$
\begin{gathered}
q_{1}(0)=0, \dot{q}_{1}(0)=0, q_{2}(0)= \\
=0, \dot{q}_{2}(0)=0, I(0)=0 .
\end{gathered}
$$

The equations of motion (5), (2), the electromechanics equations (6), (7) and the initial conditions (8) represent the developed mathematical model of the robotic wheeled transport platform for horizontal displacements of nuclear fuel. This model demonstrates that the acceleration of horizontal transportation of nuclear fuel is determined by the voltage supplied on the drive electric motors, so the smooth movement can be realized by choosing this voltage. Besides, this model allows considering the coupled motions of the wheeled platform and the 
inertial component of the on-board accelerometer to ensure substantiation of the instrumental measurements for tracking actual transportation loads on the nuclear fuel assembly.

\section{Computer simulations of horizontal transportation of the nuclear fuel assemblies on four-wheeled robotic platform}

The Scilab free open source software will be used for computer simulation of the dynamic processes in the moving robotic transport wheeled platform with the installed on-board accelerometer and the nuclear fuel assembly cargo. The computer simulation is actually reduced to numerical solution of the differential equations (5), (2), (6), (7) with the initial conditions (8) representing the mathematical model of the considered processes. However, the most of known applicable for these numerical methods require representing the differential equations (5), (2), (6), (7) and the initial conditions (8) in the canonical view of the system of first order ordinary differential equations. To do this we will introduce the new variables:

$$
x_{1}=q_{1}, x_{2}=q_{2}, x_{3}=\dot{q}_{1}, x_{4}=\dot{q}_{2}, x_{5}=l \text {. }
$$

The new variables (9) will allow reducing the differential equations (5), (2), (7) with the relation (6) and the initial conditions (8) in the follows system of first order differential equations:

$$
\begin{aligned}
& \dot{x}_{1}=x_{3}, \\
& \dot{x}_{2}=x_{4}, \\
& \dot{x}_{3}=f_{1}\left(x_{2}, x_{3}, x_{4}, x_{5}\right), \\
& \dot{x}_{4}=f_{2}\left(x_{2}, x_{3}, x_{4}, x_{5}\right), \\
& \dot{x}_{5}=f_{3}\left(x_{3}, x_{5}\right), \\
& x_{1}(0)=0, x_{2}(0)=0, x_{3}(0)= \\
& =0, x_{4}(0)=0, x_{5}(0)=0,
\end{aligned}
$$

where $f_{1}\left(x_{2}, x_{3}, x_{4}, x_{5}\right), f_{2}\left(x_{2}, x_{3}, x_{4}, x_{5}\right)$ and $f_{3}\left(x_{3}, x_{5}\right)$ are certain functions representing the differential equations (5), (2) and (7) by means of the new variables (9) taking into account the relation (6). These functions can be represented as follows:

$$
\begin{gathered}
\left(\begin{array}{l}
f_{1}\left(x_{2}, x_{3}, x_{4}, x_{5}\right) \\
f_{2}\left(x_{2}, x_{3}, x_{4}, x_{5}\right)
\end{array}\right)= \\
=\left(\begin{array}{cc}
m & -m_{a} \\
-m_{a} & m_{a}
\end{array}\right)^{-1}\left(\begin{array}{c}
F\left(x_{3}, x_{5}\right)+\left|F\left(x_{3}, x_{5}\right)\right| \\
-c_{\mathrm{a}} x_{2}-\beta_{\mathrm{a}} x_{4}
\end{array}\right),
\end{gathered}
$$

$$
f_{3}\left(x_{3}, x_{5}\right)=\frac{u(t)}{L}-\frac{B}{R_{w} L} x_{3}-\frac{R}{L} \cdot x_{5} \text {, }
$$

$$
\text { where } F\left(x_{3}, x_{5}\right)=\frac{4}{R_{w}}\left(B x_{5}-M_{\mathrm{rf}} \operatorname{sign}\left(x_{3}\right)\right)-b x_{3}\left|x_{3}\right| \text {. }
$$

The equations (10), (12), (13) and the initial conditions (11) are realized by using the Scilab software graphic tools as shown on the Figure 2. The presented model (Figure 2) actually includes definition of the ordinary differential equation (10) with computing by the formulas (12), (13). It is necessary to note separately, that solution of the linear equations (12) is realized directly by multiplying on the inverse matrix, which needs to be calculated before using the model (Figure 2) because it is possible due to the small matrix' size.

The voltage supplied on the drive electric motors during the triggering mode will be assumed as follows:

$$
u(t)=U \cdot \begin{cases}\left(t / t_{\mathrm{sw}}\right)^{k}, & 0 \leq t<t_{\mathrm{sw}} \\ 1, & t \geq t_{\mathrm{sw}}\end{cases}
$$

where $U$ is a certain preset value of the voltage to be established; $t_{\mathrm{a}}$ is the switching time; $k$ is the parameter of the voltage increasing law.

Modelling the voltage (14) by using the Scilab software is presented on the Figure 3. Although, the instantly supplied voltage theoretically can be imagined as the limit transition of the generally represented voltage (14), but due to dividing on zero it is necessary to have the switch for considering this case (Figure 3). It seems that the smooth motions during the triggering mode of the robotic wheeled transport platform with the nuclear fuel can be realized by means of the corresponding chosen parameters of the supplied voltage (14). The voltage value $U$ to be established have to be chosen considering the required velocity of transportation the nuclear fuel, but the value $t_{\mathrm{a}}$ of the switching time and the value $k$ of the voltage increasing law have to be chosen to limit the accelerations during the triggering mode.

\section{Results of the computer simulations and their interpretation}

To make the computer simulation of the nuclear fuel transportation on the robotic wheeled platform by using the developed models (see Figure 2 and Figure 3 ) it is necessary to define all required data, which has to be represented as the variables of the Scilab workspace. Next, we will assume the model task with the follows parameters: 


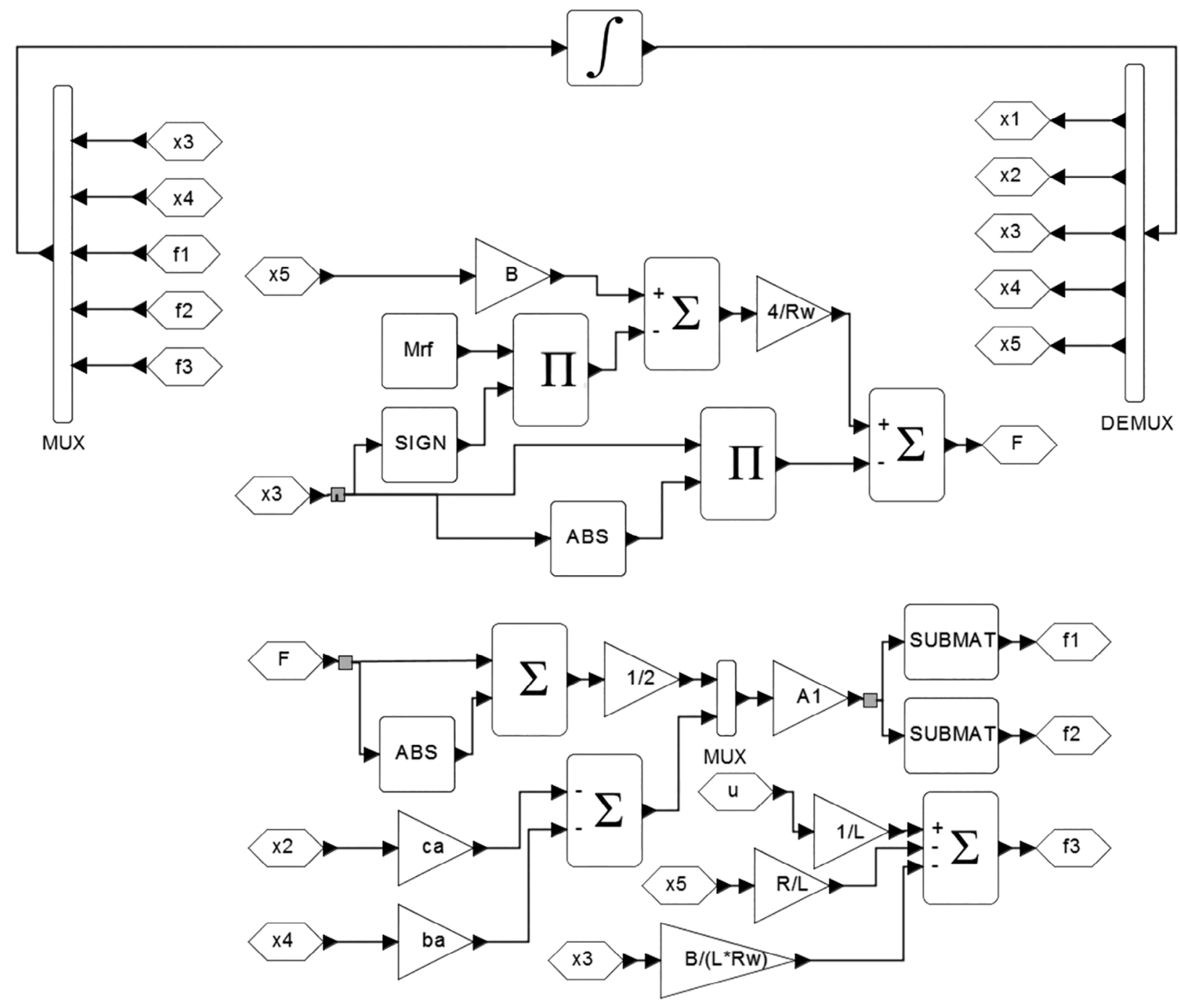

Figure 2 - The mathematical model's representation in the Scilab software

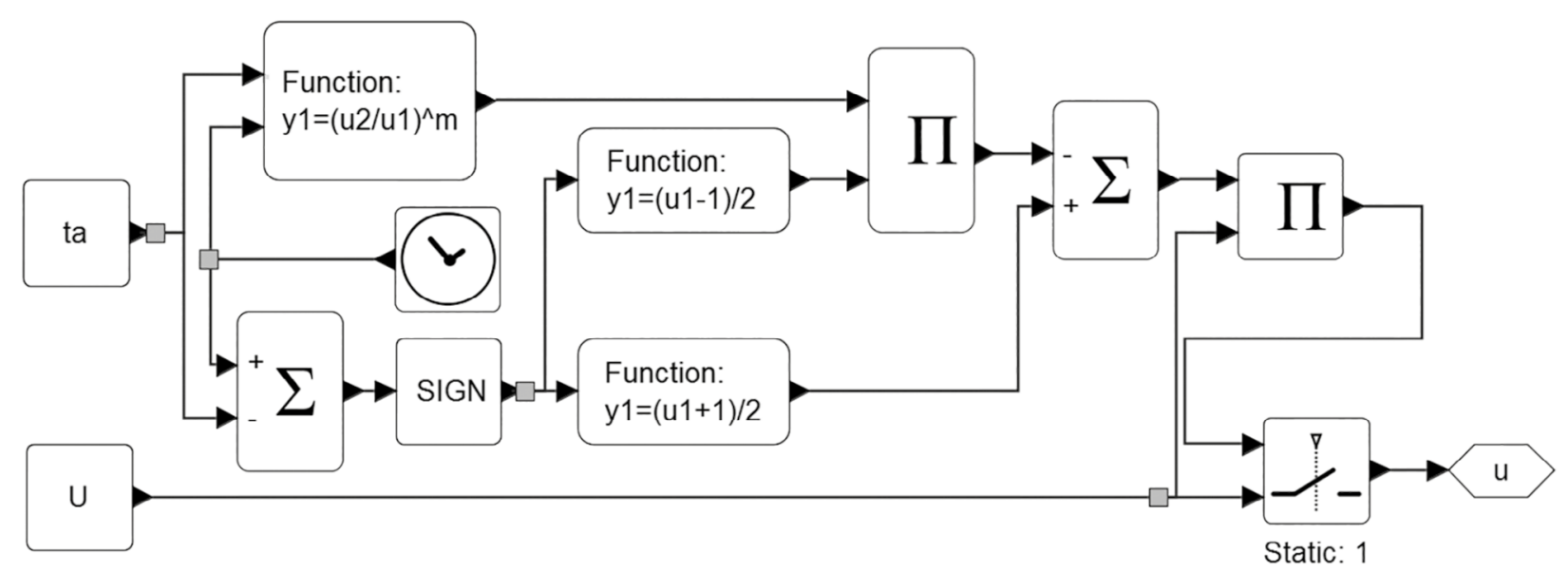

Figure 3 - Forming the voltage supplied on the drive electric motors in the Scilab software 


$$
\begin{gathered}
m_{\mathrm{NFA}}=750 \mathrm{~kg}, m_{\mathrm{p}}=2250 \mathrm{~kg}, \\
b=0,405 \frac{\mathrm{N} \cdot \mathrm{s}^{2}}{\mathrm{~m}}, f_{\mathrm{rf}}=0,015, \\
m_{\mathrm{w}}=20 \mathrm{~kg}, R_{\mathrm{w}}=0,15 \mathrm{~m}, J_{\mathrm{w}}=0,225 \mathrm{~kg} \cdot \mathrm{m}^{2}, \\
m_{\mathrm{r}}=16 \mathrm{~kg}, J_{\mathrm{r}}=0,0032 \mathrm{~kg} \cdot \mathrm{m}^{2}, \\
R=1,180 \mathrm{~m}, \mathrm{~L}=2,6 \mathrm{mH}, \\
\tau_{M}=16,8 \frac{\mathrm{mOm} \cdot \mathrm{A}^{2} \cdot \mathrm{s}^{4}}{\mathrm{~kg} \cdot \mathrm{m}^{2}}, \\
U=20 \mathrm{~V}, \mathrm{k}=1, \\
m_{\mathrm{a}}=0,001 \mathrm{~kg}, c_{\mathrm{a}}=0,01 \frac{\mathrm{N}}{\mathrm{m}}, \beta_{\mathrm{a}}=0,001 \frac{\mathrm{N} \cdot \mathrm{s}}{\mathrm{m}} .
\end{gathered}
$$

The computer simulation results for the input data (15)-(19) are presented on the Figure 3-6. Reliability of these results can be substantiated by presence of the maximum velocity limited by the correlation between total motion force and resistance (Figure 4) well-known for all wheeled transport platforms.

Obtained results showed (Figure 5) that increasing the switching time $t_{\mathrm{a}}$ the parameter of the gradual increase of supplied voltage (14) have led to decreasing the transport acceleration of the nuclear fuel almost twice comparing with the case of instantly supplied voltage on the drive electric motors; this can be explained by increasing the time needed for achievement of the maximal possible velocity of the wheeled transport platform. Due to these circumstances, we have the opportunities to increase the switching time to have sufficiently small acceleration of nuclear fuel transportation by means the four-wheeled transport platform. At the same time, it is difficult to exactly provide manually the required supplied voltage (14) corresponding to the exactly set value $t_{\mathrm{a}}$ of the switching time, so, automated control of supplied voltage on the drive electric motors of the wheeled platform used for transportation the nuclear fuel is required. Modelling of the installed accelerometer (Figure 6) shows that the maximum displacement of the inertial element can be very sensitive to the motion modes of the wheeled platform, so it will allow recording all the harsh motions with the higher accelerations to have estimations on possible transport damages of the nuclear fuel.

The strains, the distortions and the stresses in some part of the nuclear fuel assembly during the transportation can be found by solving the follows dynamic theory of elasticity problem:

$$
\begin{gathered}
\varepsilon_{i j}=\frac{1}{2}\left(\frac{\partial u_{i}}{\partial y_{j}}+\frac{\partial u_{j}}{\partial y_{i}}\right), \\
\frac{\partial \sigma_{i j}}{\partial y_{j}}-\rho\left(g_{i}+k_{i} \ddot{q}_{1}+\frac{\partial^{2} u_{i}}{\partial t^{2}}\right)=0, \\
\sigma_{i j}=C_{i j k l} \varepsilon_{k l},
\end{gathered}
$$

$$
\begin{gathered}
\left.u_{i}\right|_{S_{u}}=u_{i}^{*},\left.\sigma_{i j} n_{j}\right|_{S_{p}}=p_{i},\left.u_{i} n_{i}\right|_{S_{C}}= \\
=u_{C} ;\left.u_{i}\right|_{t=0}=0,\left.\frac{\partial u_{i}}{\partial t}\right|_{t=0}=0
\end{gathered}
$$

where $y_{i}, i=1,2,3$ are the Cartesian coordinates of the considered part's point;

$\varepsilon_{i j}, u_{i}$ and $\sigma_{i j}$ are the strain tensor's, the displacement vector's and the stress tensor's components;

$g_{i}$ are the components of the gravity load;

$k_{i}$ are the parameters defining the transportation acceleration components depending on the orientation of the nuclear fuel on the wheeled platform;

$\rho$ and $C_{i j k l}$ are the density and the elastic properties tensor of the structural material;

$u_{i}^{*}$ are the given displacement's components on the $S_{u}$ part of the boundary surface;

$n_{j}$ are the components of the unit vector in normal position to the boundary surface;

$p_{i}$ are given surface loading components on the $S_{p}$ part of the boundary surface; $u_{c}$ is the given deviation of the rigid body on the $S_{C}$ part of the boundary surface.

As it is demonstrated by the equations (20), simulating the transportation accelerations (Figure 5) is essentially required for defining those permissible values by assessing the strains, the distortions and the stress in the parts of the nuclear fuel assemblies, but such definition is the separate problem planned to be considered further. At the same time, possibilities of decreasing the transport accelerations (Figure 5) are the principal issues for providing safe horizontal technological displacements of the nuclear fuel by using fully automated robotic wheeled platform. It seems prospective considering possibility to exclude close contact of the industrial staff with the radioactive materials.

\section{Conclusions}

These researches allowed developing the theoretical background for safe onsite horizontal transportation of nuclear fuel by means of the robotic wheeled platforms, which allows significantly reducing hazardous impact of nuclear materials on the industrial staff due to implementing automated motion control. Although this research is just the initial one and will be definitely continued, but having carried it out allowed obtaining certain important results.

The mathematical model of nuclear fuel horizontal transportation on the wheeled robotic platform with the on-board recording accelerometer was developed based on the dynamics and the electro-mechanics. This model envisages defining transportation accelerations of nuclear fuel as well 


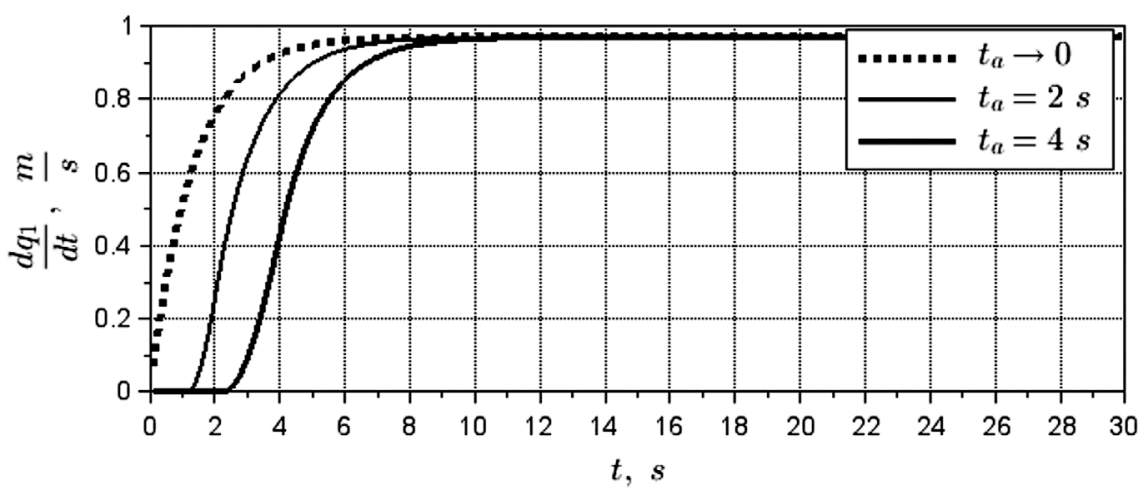

Figure 4 - Transportation velocity of nuclear fuel

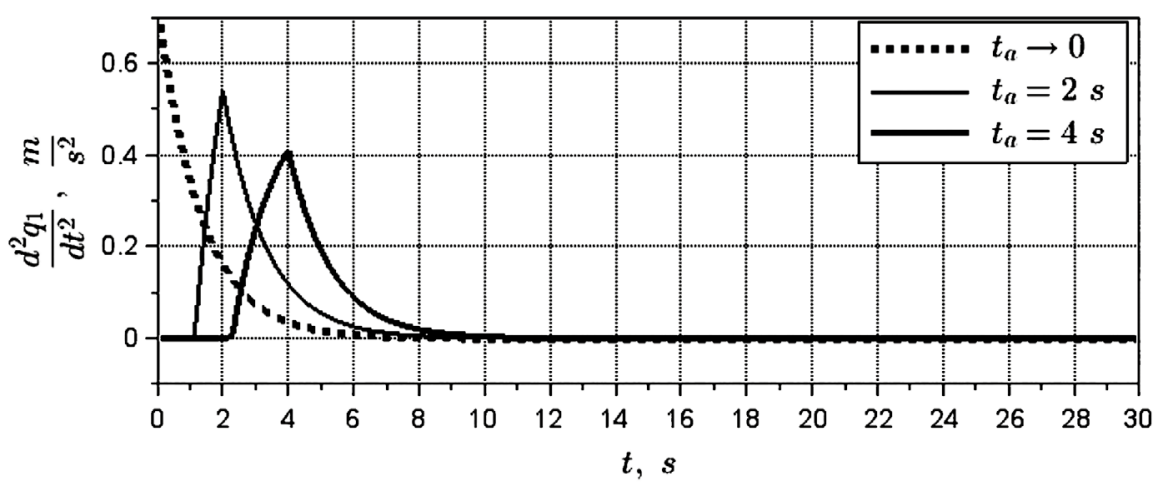

Figure 5 - Transportation acceleration of nuclear fuel

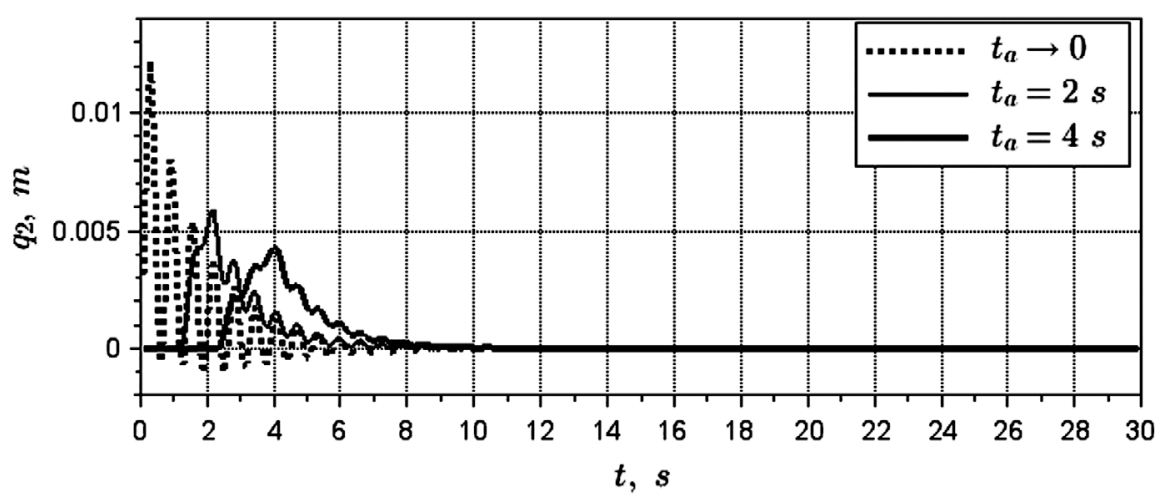

Figure 6 - Displacement of the inertial element of the on-board measurement accelerometer

as motion of the inertial element of the on-board recording accelerometer depending on the supplied voltage on the drive electric motors of the robotic wheeled platforms. It is demonstrated that it is possible to ensure small enough acceleration of transportation for full excluding damages of nuclear fuel assembly carried on the wheeled robotic platform due to a particular choice of the supplied voltage on the drive electric motors. All these opportunities can definitely be implemented by using the automated control only. The maximum displacement of the inertial element of the on-board accelerometer can be very sensitive to the motion modes of the wheeled platform, so it will allow recording all the harsh motions with higher accelerations to have estimation of possible transport damages of the nuclear fuel assemblies.

The work was carried out under the scientific project "Intelligent Multifunctional Robotic Platform with Improved Manipulator Using Capabilities" (reg. No 0121U109909) funded by the Ministry of Education and Science of Ukraine with partial support of the National Academy of Sciences of Ukraine under grants for research laboratories/groups of the young scientists for investigations on priority areas of the science and technology development 2020-2021 (No. 0120U100116). 


\section{References}

1. Romashov, Yu. V., Povolotskii, E. V. (2018). Influence of the Temperature State on the Damageability Due to the Creep of Claddings of Cylindrical Fuel Elements. Visnyk of V.N.Karazin Kharkiv National University Ser. "Mathematics, Applied Mathematics and Mechanics", 87, 13-28. doi: 0.26565/2221-5646-2018-87-02.

2. Alyokhina, S. (2019). Thermal State of Ventilated Storage Container with Spent Nuclear Fuel under Normal Operation. International Journal of Nuclear Energy Science and Technology, 13(4), 381-398. doi: 10.1504/IJNEST.2019.106056

3. Tsitsimpelis, I., Taylor, C. J., Lennox, B., Joyce, M. J. (2019). A Review of Ground-Based Robotic Systems for the Characterization of Nuclear Environments. Progress in Nuclear Energy, 111, 109-124. doi: 10.1016/j.pnucene.2018.10.023.

4. Kim, I. S., Choi, Y., Jeong, K.M. (2017). A New Approach to Quantify Safety Benefits of Disaster Robots. Nuclear Engineering and Technology, 49 (7), 1414-1422. doi: 10.1016/j.net.2017.06.008.

5. Starý, M., Novotný F., Horák, M., Stará, M. (2020). Sampling Robot for Primary Circuit Pipelines of Decommissioned Nuclear Facilities. Automation in Construction, 119, 103303. doi: 10.1016/j.autcon.2020.103303.

6. Song, B., Park, J., Yun, D. (2020). Depth-adaptive Controller for Spent Nuclear Fuel Inspections. Nuclear Engineering and Technology, 52(8), 1669-1676. doi: 10.1016/j.net.2020.01.019.

7.Shin, H.,Jung, S. H., Choi,Y. R., Kim, C. H.(2018). Development of a Shared Remote Control Robot for Aerial Work in Nuclear Power Plants. Nuclear Engineering and Technology, 50(4), 613-618. doi: 10.1016/j.net.2018.03.006.

8. Ghosh, A., Soto, D. A. P., Veres, S. M., Rossiter, A. (2020) Human Robot Interaction for Future Remote Manipulations in Industry 4.0. IFAC-PapersOnLine, 53(2), 10223-10228. doi: 10.1016/j.ifacol.2020.12.2752.

\section{Безпека транспортування ядерного палива на колісних роботизованих платформах}

\author{
Альохіна С. В. ${ }^{1,2}$, Невлюдов І. Ш. ${ }^{2}$, \\ Ромашов Ю. В. ${ }^{2}$
}

'Інститут проблем машинобудування ім. А. М. Підгорного НАН України, м. Харків, Україна

${ }^{2}$ Харківський національний університет радіоелектроніки, м. Харків, Україна

Розглядаються питання щодо забезпечення безпеки під час здійснення операцій горизонтального транспортування ядерного палива в межах підприємств. 3 урахуванням сучасних тенденцій щодо впровадження роботизованих систем для зменшення впливів на персонал небезпечних ядерних матеріалів, досліджено питання про автоматизо- ване управління рухом колісної роботизованої платформи, яка може використовуватися для горизонтального транспортування ядерного палива. Основна увага приділяється мінімізації транспортних навантажень на ядерне паливо завдяки зменшенню прискорень під час його горизонтального переміщення на колісній роботизованій платформі, що $\epsilon$ окремим питанням комплексної проблеми безпеки поводження із ядерним матеріалами. Дослідження безпеки горизонтального переміщення ядерного палива на роботизованій колісній транспортній платформі зводяться до визначення прискорень та виконання з допомогою комп'ютерного моделювання з використанням математичних моделей динаміки та електромеханіки. У вигляді рівнянь Лагранжа другого роду та рівнянь електромеханіки рушійних двигунів постійного струму побудовано математичну модель роботизованої колісної транспортної платформи, завантаженої ядерним паливом, та встановленого на ній акселерометра, який забезпечує вимірювання, необхідні для автоматизованої системи безпечного управління рухом. Досліджено питання щодо забезпечення плавності ходу під час зрушення з місця колісної платформи, завантаженої ядерним паливом, оскільки саме на такому режимі спостерігаються максимальні прискорення, що можуть призвести до пошкоджень ядерного палива. Комп'ютерне моделювання виконане за допомогою вільного програмного забезпечення Scilab із відкритим програмним кодом. Показано, що завдяки належному вибору закону зміни у часі напруги живлення рушійних електричних двигунів можна забезпечити досить мале прискорення під час зрушення з місця роботизованої колісної транспортної платформи, завантаженої ядерним паливом. Одержаний результат обгрунтовує можливість безпечного горизонтального транспортування ядерного палива на роботизованих колісних платформах у межах підприємств, що суттєво зменшить шкідливий вплив небезпечних ядерних матеріалів на персонал.

Ключові слова: автоматизація, безпека, колісна транспортна платформа, математична модель, плавність руху, поводження, програмне управління, ядерне паливо.

Отримано 03.07.2021 